\title{
Prediksi Rembesan Pada Dinding Embung UNNES Berdasarkan Data Geolistrik
}

\author{
Supriyadi $^{1}$, Hizbulwathon Wirayuda ${ }^{2}$, Khumaedi $^{3}$ \\ 1,2,3 Fisika, Universitas Negeri Semarang \\ email : supriyadi@mail.unnes.ac.id
}

\begin{abstract}
The background of this research is the physical condition of the UNNES reservoir which needs attention after so many years of construction. This is an effort to maintain the sustainability of the reservoir function to capture rainwater so that it can be used in the dry season, and an effort to maintain the embung as one of the identities of UNNES as a university with a conservation perspective. In general, this study aims to determine the physical condition of the embung walls. This research was conducted at the edge of the reservoir at the State University of Semarang to determine the subsurface structure of the local location. The method used is resistivity resistivity by mapping or horizontally. The configuration used is the Wenner configuration. Based on the geoelectric survey, the resistivity value ranges from $2.7 \Omega \mathrm{m}-177 \Omega \mathrm{m}$, it can be seen that the most layers are sand and gravel. These two layers are easy to penetrate, allowing water in the embung to seep into the embung walls. Evidence of seepage is not visible on the wall of the embung, this is because the wall of the embung is in the ground, it does not appear on the ground.
\end{abstract}

Keywords: seepage, wall, reservoir, geoelectric

\begin{abstract}
Abstrak: Latar belakang penelitian ini adalah kondisi fisik embung UNNES yang perlu mendapat perhatian setelah sekian tahun dibangun. Hal ini sebagai upaya menjaga keberlangsungan fungsi embung untuk menangkap air curah hujan sehingga dapat dimanfaatkan pada musim kemarau, dan upaya mempertahankan embung sebagai salah satu identitas UNNES sebagai universitas yang berwawasan konservasi. Penelitian ini secara umum bertujuan untuk mengetahui kondisi fisik dinding embung.Penelitian ini dilakukan di sisi pinggir embung Universitas Negeri Semarang untuk mengetahui struktur bawah permukaan lokasi setempat. Metode yang digunakan adalah resistitivitas tahanan jenis dengan cara mapping atau secara horisontal. Konfigurasi yang digunakan adalah konfigurasi Wenner. Berdasarkan survei geolistrik, nilai resistivitas berkisar antara 2,7 $\Omega \mathrm{m}-177 \Omega \mathrm{m}$, terlihat secara keseluruhan lapisan yang paling banyak adalah lapisan pasir dan kerikil. Kedua lapisan ini mudah untuk ditembus sehingga memungkinkan air dalam embung rembes pada dinding embung. Bukti rembesan tidak nampak pada dinding embung, hal ini dikarenakan karena dinding embung berada di dalam tanah, tidak muncul di permukaan tanah.
\end{abstract}

Kata kunci: rembesan, dinding, embung, geolistrik

\section{PENDAHULUAN}

Keberadaan embung di kampus UNNES tiadak bisa dilepaskan dengan visi UNNES sebagai kampus yang berwawasan konservasi dan bereputasi internasional yang dideklarasikan sebagai universitas konservasi pada tanggal 12 Maret 2010 oleh Menteri Pendidikan dan Kebudayaan M. Nuh. Konsep konservasi ini didasarkan pada Permendiknas No.8 tahun 2011. Konservasi menjadi bagian penting bagi UNNES, hal ini ditunjukkan dengan terintegrasinya konservasi menjadi visi berdasarkan statuta UNNES.

Di awal perkembangannya untuk menopang visi UNNES menuju kampus yang berwawasan konservasi, maka dibetuk satu tim yang bertugas sebagai pengembang konservasi, yaitu 
Badan Pengembang Konservasi UNNES. Tim ini merupakan penggerakan dan pelaksana teknis kegiatan-kegiatan UNNES terkait dengan pengembangan Universitas Konservasi. Ada tujuh divisi yang dimiliki badan pengembang ini, yaitu (1) divisi biodeversiy conservation, (2) green architecture and internal transportation, (3) paperless policy, (4) clean energy, (5) waste management, (6) conservation of art and cultural, dan (7) kader konservasi (Fitiyah, 2015).

Badan Pengembang Konservasi mempunyai tugas mengawal dan menyelenggarakan berbagai aktivitas kampanye. Kegiatan kampanye dimulai dari internal dan luar UNNES. Kegiatan-kegiatan tersebut berupa konsep berupa konsep hingga aktivitas yang melibatkan banyak pihak baik dalam dan luar UNNES. Salah satu kegiatan adalah yang dilaksanakan oleh divisi green architecture and internal transportation yang berupa pembuatan embung. Pembuatan embung dilaksanakan oleh Unit Layanan Pengadaan UNNES bekerjasama dengan Kementerian Kehutanan Republik Indonesia. Kegiatan ini bertujuan untuk meningkatkan daya dukung sumber daya air terutama perbaikan kuantitas dan kualitas air tanah di wilayah kecamatan Gunungpati dan sekitarnya dengan pembangunan embung di kampus UNNES. Di awal pembangunannya, embung diharapkan memiliki fungsi utama sebagai penabung air hujan di daerah sekitar kampus. Namun pada perkembangannya, embung juga dimanfaatkan sebagai sarana rekreasi oleh mahasiswa dan masyarakat setempat. Kawasan embung juga dilengkapi dengan bale-bale, taman dengan bangku dan 2 peenerangan yang memadai menjadikannya sebagai tempat favorit di sore dan malam hari. Embung juga dijadikan sebagai tempat memancing. Hal ini memungkinkan, mengingat terdapat ikan di embung tersebut karena sering dilepas bibit ikan. Seiring berjalannya waktu, kenyataan di lapangan menunjukkan bahwa sekarang embung mengalami banyak perubahan dari kualitas lingkungan dan fungsi. Air yang ditampung embung Unnes sangatlah keruh, berbau busuk, dan berwarna hijau bak sungaisungai di Jakarta. Seluruh area embung juga dipenuhi dengan sampah plastik dan anorganik lainnya, baik di embung maupun di jalan-jalan di tepi embung. Dari sisi pemanfaatan oleh mahasiswa, embung kini dijadikan tempat berpacaran oleh mahasiswa di malam hari. Dengan kualitas air yang sangat keruh tersebut, kadangkala di sore hari embung digunakan oleh anakanak warga sekitar untuk mandi padahal sudah terpampang dengan jelas larangan untuk mandi di embung karena berbahaya. Tentu hal ini sangat membahayakan dan tidak baik bagi kesehatan mereka, menimbang air di embung kini sangat tercemar. Liesnoor et al (2015) menyatakan bahwa kondisi genangan air di oulet embung pada musim hujan (1) Genangan air terjadi di Kampus FIS, FH, FE, FMIPA dan FBS karena saluran air yang tidak dapat menampung run off saat hujan turun, (2) Kerugian yang ditimbulkan antara lain genangan air di sekitar embung karena tidak ada drainase.

\section{METODE PENELITIAN}

Lokasi penelitian berada di embung UNNES pada posisi LS $7^{\circ} 2^{\prime} 53,8^{\prime \prime}$ dan BT $110^{\circ}$ 23'40,5' (Gambar 4). Embung ini tepatnya bersebelahan dengan masjid kampus Ulul Albab.

Penelitian ini dilakukan di sisi pinggir embung Universitas Negeri Semarang untuk mengetahui struktur bawah permukaan lokasi setempat. Metode yang digunakan adalah resistitivitas tahanan jenis dengan cara mapping atau secara horisontal. Konfigurasi yang digunakan adalah konfigurasi Wenner dikarenakan konfigurasi wenner mempunyai kelebihan dalam ketelitian pembacaan dengan nilai eksentrisitas tidak besar yaitu bernilai $1 / 3$, selain itu konfigurasi wenner merupakan konfigurasi yang memiliki sinyal yang bagus dibandingkan dengan konfigurasi lainnya. Alat yang digunakan pada penelitian ini yaitu Resistivitymeter Bawono- Georesist 12 GM-INV dengan spasi 5 meter dan jarak bentangan 75 meter pada tiap lintasannya . Data yang didapat pada peneliltian berupa kuat arus listrik (I) dan beda potensial 
$(\Delta \mathrm{V})$. Dengan data tersebut, maka dapat diperoleh nilai resistivitas semu melalui pengolahan data.

Adapun langkah-langkah pengerjaan studi, sebagai berikut:

1. Pengumpulan data berupa data lokasi daerah yang akan diukur melalui Google Earth

2. Perencanaan pengukuran, berdasarkan panjang garis kemudian dapat direncanakan kombinasi perletakan elektroda C1, C2, P1 dan P2.

3. Survey pendahuluan di lapangan dilakukan untuk melihat potensi rembesan visual.

4. Pengukuran geolistrik menggunakan konfigurasi Wenner Schlumberger dilakukan setelah proses perencanaan telah menghasilkan hasil yang dibutuhkan berupa, posisi, jarak, spasi.

5. Perhitungan hasil pengukuran di lapangan menghasilkan data berupa arus (I) serta tegangan (V) yang diperoleh melalui pembacaan alat geolistrik.

6. Pengolahan software RES2DINV, hasil pengolahan ini berupa gambar melintang dengan kombinasi warna yang mewakili jenis-jenis batuan.

7. Pembacaan jenis batuan dan dilakukan analisis rembesan embung.

\section{HASIL DAN PEMBAHASAN}

Lokasi lintasan 1 terletak pada koordinat $7^{\circ} 02^{\prime} 54.85^{\prime \prime}$ LS - 110²3'39.60"BT. Penampang resistivitas lapisan bawah permukaan $2 \mathrm{D}$ pada lintasan 1 dengan 5 iterasi dan root mean square $(\mathrm{rms})=9,4 \%$ dapat dilihat pada Gambar 1

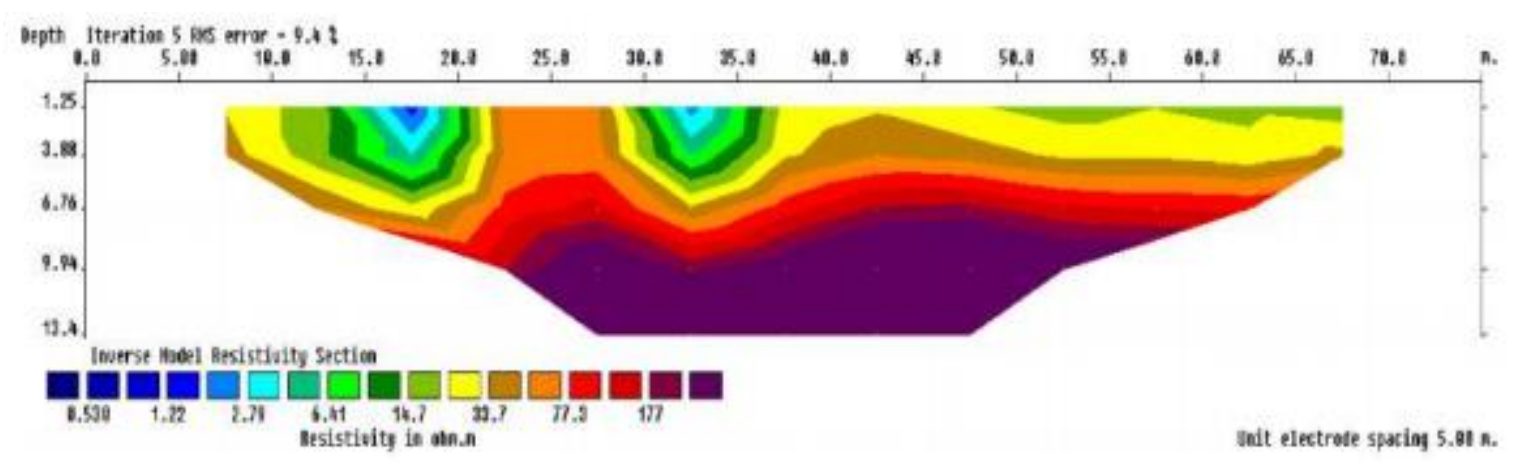

Gambar 1. Hasil Pengukuran lintasan 1

Berdasarkan Gambar 1 terlihat terdapat 4 lapisan yaitu lapisan pasir tufan dan air, lapisan lempung, lapisan pasir dan kerikil serta lapisan aliran lahar/breksi. Lapisan pasir dan tufan ditunjukkan pada titik 15-20 dengan kedalaman 0-3,88 meter dan titik 30-35 dengan kedalaman 0-2 meter. Lapisan lempung ditunjukkan pada titik 7-22 dengan kedalaman 0-6,76 meter dan titik 28-75 dengan kedalaman 0-6 meter. Lapisan pasir dan kerikil ditunjukkan pada titik 22-28 dengan kedalaman 0-8 meter dan letaknya tepat berada dibawah lapisan lempung mendatar, sedangkan lapisan aliran lahar/breksi ditunjukkan dengan kedalaman 6-13,4 meter dan letaknya dibawah lapisan pasir dan kerikil.

Lokasi lintasan 2 terletak pada koordinat $7^{\circ} 02^{\prime} 53.04^{\prime \prime}$ LS - 110²3'41.62" BT. Penampang resistivitas lapisan bawah permukaan $2 \mathrm{D}$ pada lintasan 2 dengan 5 iterasi dan root mean square $(\mathrm{rms})=18,5 \%$ dapat dilihat pada Gambar 2 


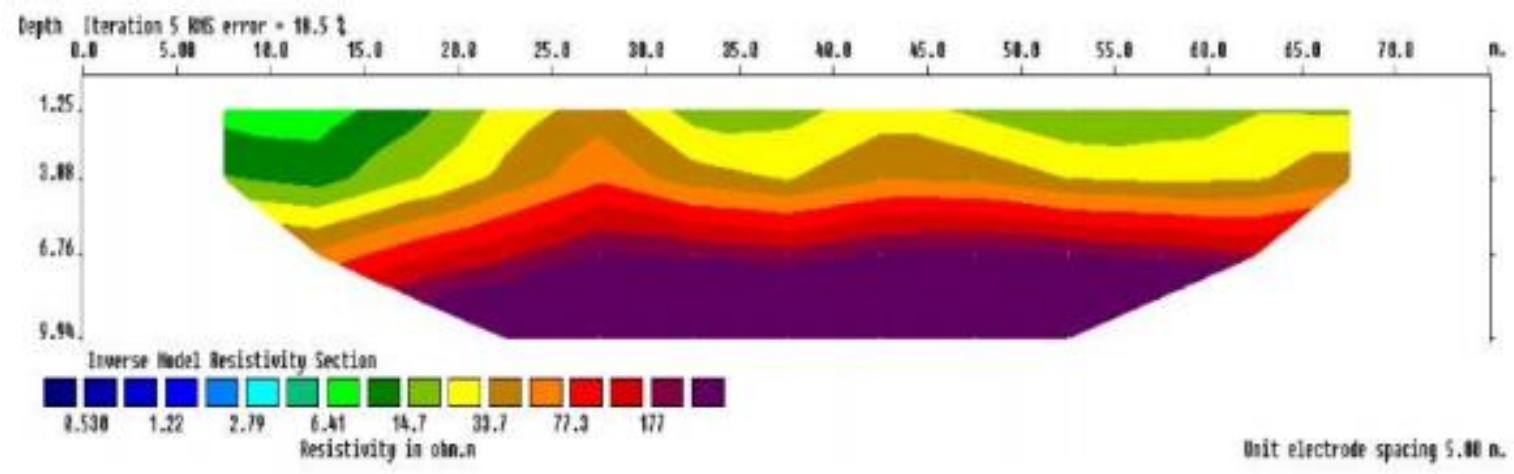

Gambar 2. Hasil Pengukuran lintasan 2

Berdasarkan Gambar 2 terlihat terdapat 3 lapisan yaitu lapisan lempung, lapisan pasir dan kerikil serta lapisan aliran lahar/breksi. Lapisan lempung ditunjukkan pada titik 0-22 dengan kedalaman 0-5 meter, titik 32-40 dengan kedalaman 0-2 meter dan titik 46-68 dengan kedalaman 0-3 meter. Lapisan pasir dan kerikil ditunjukkan pada titik 22-32 dengan kedalaman 0-7 meter dan titik 40-46 dengan kedalaman 0-7 meter serta letaknya tepat berada dibawah lapisan lempung mendatar, sedangkan lapisan aliran lahar/breksi ditunjukkan dengan kedalaman 5-9,94 meter dan letaknya dibawah lapisan pasir dan kerikil.

Lokasi lintasan 3 terletak pada koordinat $7^{\circ} 02^{\prime} 54.71^{\prime \prime}$ LS - 110 23'41,88" BT. Penampang resistivitas lapisan bawah permukaan 2D pada lintasan 3 dengan 5 iterasi dan root mean square $(\mathrm{rms})=9 \%$ dapat dilihat pada Gambar 3

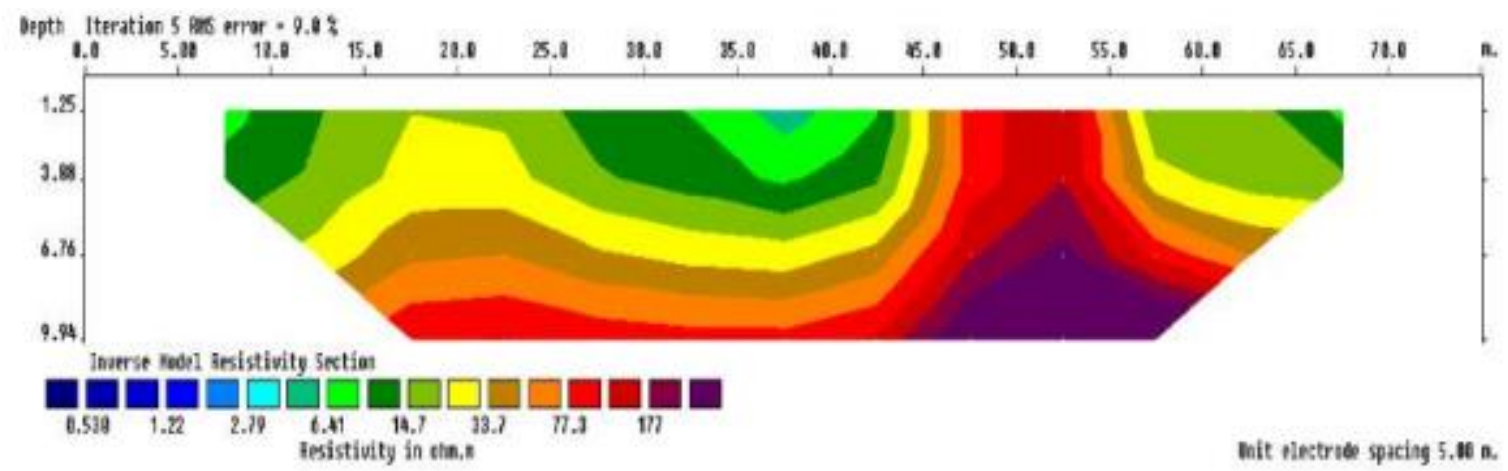

Gambar 3. Hasil Pengukuran lintasan 3

Berdasarkan Gambar 3 terlihat terdapat 3 lapisan yaitu lapisan lempung, lapisan pasir dan kerikil serta lapisan aliran lahar/breksi. Lapisan lempung ditunjukkan pada titik 0-44 dengan kedalaman 0-6,76 meter dan titik 57-75 dengan kedalaman 0-5 meter. Lapisan pasir dan kerikil ditunjukkan pada titik 44-47 dengan kedalaman 0-9 meter dan titik 54-57 dengan kedalaman 07 meter, sedangkan lapisan aliran lahar/breksi ditunjukkan pada titik 47-54 dengan kedalaman 0-9,94 meter

Dari ketiga lintasan pengukuran terdapat anomali di lintasan pertama. Rembesan diprediksi terjadi di lintasan pertama. Rembesan terjadi di kedalaman 5 meter tepatnya di bentangan 1520 meter serta 30-35 meter. 


\section{DAFTAR PUSTAKA}

Liesnoor D.S., Handayani (2015). Kajian Genangan Air Hujan pada Outlet Embung dan Partisipasi Masyarakat di Sekitar Kampus UNNES. International Journal Conservation, Vol.4, No.1, pp. 28-33

Fitriyah L., (2015). Tujuh Pliar Konservasi UNNES https://ailatulfitriyah6.wordpress.com/2015/03/21/tujuh-pilar-konservasikonservasiunnes/, diakses, 20 Maret 2019.

N K Abdullahi, G I Baba 2017. Application of Geo-electrical Imaging to Determine Signaturesof Buried Waste. Science World Journal Vol 12 (1) 2017.

Dahlin T 1996. 2 D Resistivity Surveying for Environmental and Engineering Applications. First Break 14, pp 275-283.

Loke M H 1999. Electrical Imaging Survey for Environmental and Engineering Studies.

Loke M H 2004. Tutorial: 2-D and 3-D Electrical Imaging Surveys. 